International Journal of Agriculture, Environment and Bioresearch

Vol. 4, No. 06; 2019

ISSN: $2456-8643$

\title{
ENVIRONMENTAL AND ECONOMIC INFLUENCES OF LAND OCCUPANCY IN THE COMMUNITY OF DJIDJA
}

\author{
Calixte HOUSSOU ${ }^{1}$, Auguste HOUINSOU ${ }^{1}$, José Edgard GNELE ${ }^{2}$, A. H. Brice TENT ${ }^{2}$ and Odile DOSSOU \\ GUEDEGBE ${ }^{1}$ \\ ${ }^{1}$ Laboratory of Spatial Planning, Environment and Sustainable Development (LATEDD) / FLASH / University of \\ Abomey-Calavi \\ ${ }^{2}$ Laboratory of Biogeography and Environmental Expertise (LABEE) / FASHS / University of Abomey-Calavi, \\ Benin
}

http://doi.org/10.35410/IJAEB.2019.4458

\begin{abstract}
Land resources are limited and changing at unprecedented rates. The pressure on the latter becomes daily more and more important. The objective of the study is to present the environmental and socio-economic influences of land occupation in the municipality of Djidja.

The research methodology is based on data collection, manual and statistical processing of data and analysis of results. Surveys are made from 271 heads or representatives of households and resource persons.

The basic considerations of the socio-economic scenario contribute to the reduction of the lifespan of plant formations, as these will be subject to anthropic pressures. In fact, it has been noted in the case of this scenario, an amplification of human pressures in particular, the extension of plantings, the intensification of shifting cultivation on slash-and-burn, the massive destruction of natural plant formations with the consequent naked and soil pollution, amplification of water and wind erosion followed by huge losses of agricultural land. , agricultural producers, through their various associations are informed and integrated into the environmental management plan, through the creation and operation of several local action committees. When these different conditions are met, we will see the horizon 2050, environmental stability with an equitable distribution of different units of land use in the municipality of Djidja. This situation will prevent the study area from the climatic disturbances that it has suffered for decades. In short, the scenario of environmental stability or scenario " Alafia " is that desired for a sustainable management of the environment in the Municipality of Djidja. The overall performance of the simulation is $87.15 \%$ with a Kappa index of $83 \%$. The results according to the types of units of occupation are relatively homogeneous, since they exceed $70 \%$ of precision for the producer, with however better results for artificialized units, agglomerations, fields and fallows.
\end{abstract}

Keywords: Djidja, land use, environment, socio-economic influences.

\section{INTRODUCTION}


The countries of West Africa, which are endowed with a very diversified but fragile environment, are currently undergoing rapid changes on many levels: climatic, natural, agronomic, demographic, political and socio-economic. (Akpassounou et al., 2006). For centuries, humanity has played a negligible role in the environmental equation, but this role has changed dramatically and gained in importance during the 20th century, especially over the last 50 years. As West Africa enters the 21st century, environmental changes are expected to accelerate with unknown but potentially serious consequences for both people and the environment. Of all the regions of the Earth, West Africa stands out as a particularly vulnerable region, subject to climate variability (Hulme, 2001) and driven by one of the highest global population growth rates $(2.7 \%$ per year (CILSS, 1999).

These facts are more attractive than they may seem, concerns that it is desirable to reflect upon and to explain, since they generate environmental problems other than natural erosion and insalubrity (Sagbo, 1998). 2003) in the communes of Benin in general and in the municipality of Djidja in particular. The latter is now experiencing a spatial extension. The habitat of men today dominates its landscape and threatens the survival of urban or peri-urban agriculture and consequently poses part of the problems of high dependence on food.

In addition, spatial planning has become, with the declaration of the national spatial planning policy (DEPONAT / 2002) and the requirements of sustainable development (protection of nature and living environment), a priority in the management of different types of settlements. This translates into the realization of the National and Communal Development Plans and Master Plans and the imposition of the Environmental Impact Assessment (EIA) to the different development projects as defined by the articles 87,88 et seq. Of Law 98-030 of 12 February 1999 on a framework law on the environment in the Republic of Benin. This law derives from Article 27 of Law 90-32 of 11 December 1990 on the Constitution of the Republic of Benin, which states that "everyone has the right to a healthy, satisfying and sustainable environment and has the duty to defend it. . The State takes care of the protection of the environment ". It states that no person may undertake any development, operations, facilities, plans, projects and programs or construction of a structure without following the environmental impact assessment procedure, where the latter is required by laws and regulations. The environmental impact study is the procedure that allows to determine the effects that the realization or the execution of a project can have on the environment. (Dossou, 2008).

In addition to the reasons that have just been mentioned, the requirements of decentralization have made land the first communal resource currently in high demand by the population and the local power of the municipality of Djidja. So, what are the scenarios of environmental management and institutional and endogenous measures in the municipality of Djidja? What are the environmental and socio-economic influences of land occupation in the Djidja Commune? These are all questions to be answered by the study whose objective is to determine the environmental and socio-economic influences of the land occupation in the Commune of Djidja.

\section{METHODOLOGY}

The methodological approach was based on desk research and fieldwork on the one hand, and the collection, processing and analysis of field data on the other hand. 


\subsection{Data collection techniques}

The data collection techniques used are documentary research and fieldwork.

\subsubsection{Literature search}

Literature research is essential for data collection (M-O. Safon, 2017, p.4). In this case, it consisted of visiting the documentation centers and exploring the reference websites on the theme of the dynamics of the land occupation for the consultation of some general and specific works, memoirs, journals and articles dealing with the subject. The information obtained from the literature search made it possible to take stock of the progress made on the explanatory factors of the dynamics of the occupation of the grounds and to feed the discussion.

\subsubsection{The field phase}

The field phase marks the effective presence in the municipality of Djidja for the collection of data. It breaks down into several stages:

\section{Pre-survey}

Pre-survey is a crucial step in collecting field data; it makes it possible to situate the object of study in a global context and to formulate general hypotheses (E. Salès-Wuillemin, 2006, p.8). It was essential to the present research because it made it possible to get to know the research environment before proceeding with the actual data collection.

\section{Field survey}

This phase marks the actual presence in the field of research. The field survey was rigorously conducted in the twelve (12) arrondissements of the commune of Djidja. The target groups targeted by this research are households, women's groups / associations whose activities impact the dynamics of land occupation in the municipality of Djidja. In fact, the choice of target group surveyed met the following criteria:

- have at least 30 years of age to trace the evolution of the phenomenon over time;

- have once experienced the effects of the urbanization phenomenon in the study area;

- have resided in the Commune for at least the last thirty (30) years before the investigations.

The size of the sample was deduced from the Schwartz (2002) method. It was calculated with a $95 \%$ confidence level and a margin of error of $5 \%$ using the formula opposite:

$$
N=\frac{Z \alpha^{2} \cdot P Q}{d^{2}}
$$

Where $\mathrm{N}=$ sample size by rounding;

$\mathrm{Z} \alpha=$ deviation fixed at 1.96 corresponding to a degree of confidence of $95 \%$; 
$\mathrm{P}=$ number of households in the district / number of households in the municipality;

$\mathrm{Q}=1-\mathrm{P}$

$\mathrm{d}=$ margin of error equal to $5 \%$;

Then, a rate of $15 \%$ is applied to this sample to determine the exact number of households surveyed.

In total, the sample size is two hundred and seventy-one (271) households distributed in the twelve (12) arrondissements that account the Commune and traveled. In addition to this target, the interviews are directed towards 13 municipal authorities, 24 resource persons, wise and notables and 06 groups / associations.

\subsection{Data used}

Several data were used for this research. These are among others:

- Data on demography and human constructions from INSAE statistics which made it possible to assess the evolution of the population from 1979 to 2013 on the one hand and the evolution of the buildings on the other hand;

- Meteorological data (rain, temperature, humidity) from the LACEEDE, ASECNA (MétéoBenin) statistics which allowed to appreciate the rainfall variation in the research sector;

- data relating to subdivision-resettlement, occupation, and other types of development in relation to the land problems available to the Djidja Town Hall, IGN, CENATEL which made it possible to know the evolution of the land in the sector of research ;

- Socio-anthropological data from field surveys. These data relate to actors in the urban planning and living environment sector, the management method, the constraints, the problems faced by these actors and the suggestions made by them on the basis of a pre-established questionnaire;

- Land cover data for 2000 and 2016, which made it possible to develop land cover maps based on the ecological map of Benin 1986 and the Landsat TM 1995 and ETM + 2010 images;

- Data on the state of plant formations (more specifically forests), soils, shallows, and natural drainage corridors in relation to development, occupation and land issues.

\subsection{Methods}

\subsubsection{Tools and techniques for collecting field data}

Data collection tools include the observation grid, the interview guide, and the questionnaire. These tools made it possible to collect information using appropriate techniques, in particular: 
Vol. 4, No. 06; 2019

ISSN: 2456-8643

The questionnaire survey that collected data from households, municipal officials, the CeRPA Tax, Water and Forests Department, subdivision committee members, religious and customary leaders, notable and wise and public works officers on the different forms of pressure exerted by the population on the natural environment and management of the living environment with a view to ensuring sustainable local development in the research sector;

The interview is carried out by means of an interview guide with local authorities and the persons in charge of natural resources management on the one hand, and land and urban planning on the other, in the research area ;

Direct observations have been based on the types of management that have been made and the different forms of pressure that people exert on natural resources in the research area.

\subsubsection{Data processing}

The questionnaires were the subject of a manual recount. Thus qualitative data from field surveys were captured using the Word 2010 software. Responses to each question were categorized. Then, the different categories of answers were inserted in the Excel 2010 spreadsheet for the calculation of the proportions and the realization of the graphs and tables.

The demographic projection is based on data from the 1979 censuses,

1992, 2002 and 2013 using the formula:

$$
P_{n}=P_{n-1}(1+r)^{n}
$$

With: Pn and Pn-1 respectively the projected populations and a known previous period and $\mathrm{r}$, the growth rate and $\mathrm{n}$, the time between the periods considered.

Response rates $(\operatorname{Tr})$ were calculated. They express themselves by the formula:

$$
\operatorname{Tr}=\frac{n i}{N i} * 100
$$

With Tr: Response rate; neither: the number of respondents and $\mathrm{Ni}$ the total number of respondents.

The processing of Landsat satellite imagery for the extraction of land use is the set of operations performed to derive the desired information. As part of this research, the image processing has extracted the land occupation.

Dynamic mapping of land cover types. It consists of superimposing the maps from the 1978, 1998 and 2015 land cover analysis to establish the evolution of vegetation between these two states. It allows to appreciate the evolution of the units of occupation of the soil at different periods. 
- U-1978 the area of a unit of land occupation in 1978 (U1)

U-1998 the area of the same unit in 1998 (U2) and $\Delta \mathrm{U}$, the change in the area of this land-use unit between 1978 and 1998. $\Delta \mathrm{U}=\mathrm{U} 2-\mathrm{U} 1$

If $\Delta \mathrm{U}=0$, we conclude that there is stability;

If $\Delta \mathrm{U}<0$, we conclude that there is a decrease in this unit;

If $\Delta U>0$, there is extension of this unit.

Thus, maps of occupation $(1978,1998$ and 2010) of the soil were made from the interpretation of the aerial photographs of the Kenting mission of 1978, 1998 and 2010 at the scale of 1: 80,000 and the analysis of LANDSAT TM satellite images of 1978, 1998 and 2010 at a scale of 1: 100 000. Calibration, georeferencing and image processing were done at the National Center for Remote Sensing (CENATEL) and at the LaCarto Laboratory and of the UAC Biogeography using the Arc-View software.

\section{RESULTS AND DISCUSSION}

The diachronic analysis was used to better appreciate the evolution of the identified relationships. Also, to identify, to regroup and to establish logical relations between the different parameters which the spatial dynamics of the Municipality of Djidja appeal to. A second method of analysis that is part of the concept of the PEIR model (Pressure, State, Impact and Response) was also used. The interest is to arrive from this model, to link the extensive spatial dynamics and its factors, to the land and environmental problems in the municipality of Djidja.

\subsection{Scenarios of Environmental Management and Institutional and Endogenous Strategies for Local Development in Djidja Commune}

In this section, it is a question of presenting scenarios on the one hand, and the management scenario for environmental sustainability in the Djidja Commune and the institutional and endogenous strategies developed in the Djidja Commune in relation with the local development of Djidja. somewhere else. As part of this research, two scenarios are envisaged: the socioeconomic scenario or tendency towards the catastrophe still called "Red" scenario and the scenario of environmental stability still called "green" scenario.

\subsubsection{Socio-economic Scenario or Disaster Trend ("Red" Scenario)}

This scenario is based on the socio-economic considerations in which land use dynamics took place until 2016. It does not guarantee an environmental sustainability in the Djidja commune, because, it supposes an almost total disappearance. natural formations with regard to natural resource use patterns in the study area. Thus, the following assumptions were considered:

- The extensive nature of agricultural production involves the use of environmentally harmful methods (slash-and-burn agriculture, uncontrolled deforestation, reduction of fallow periods, predominant monoculture on rotational crop in general, etc.) and degrades ecosystems in general and soils in particular (UNDP, 2000); 


\section{International Journal of Agriculture, Environment and Bioresearch}

Vol. 4, No. 06; 2019

ISSN: 2456-8643

- The population is dependent on the natural resources that constitute the main source of energy;

- The rate of land-use dynamics is increasing relative to the period from 1986 to 2016.

This scenario is considered when it is not noted an awareness of the populations of their responsibility in the degradation of the environment.

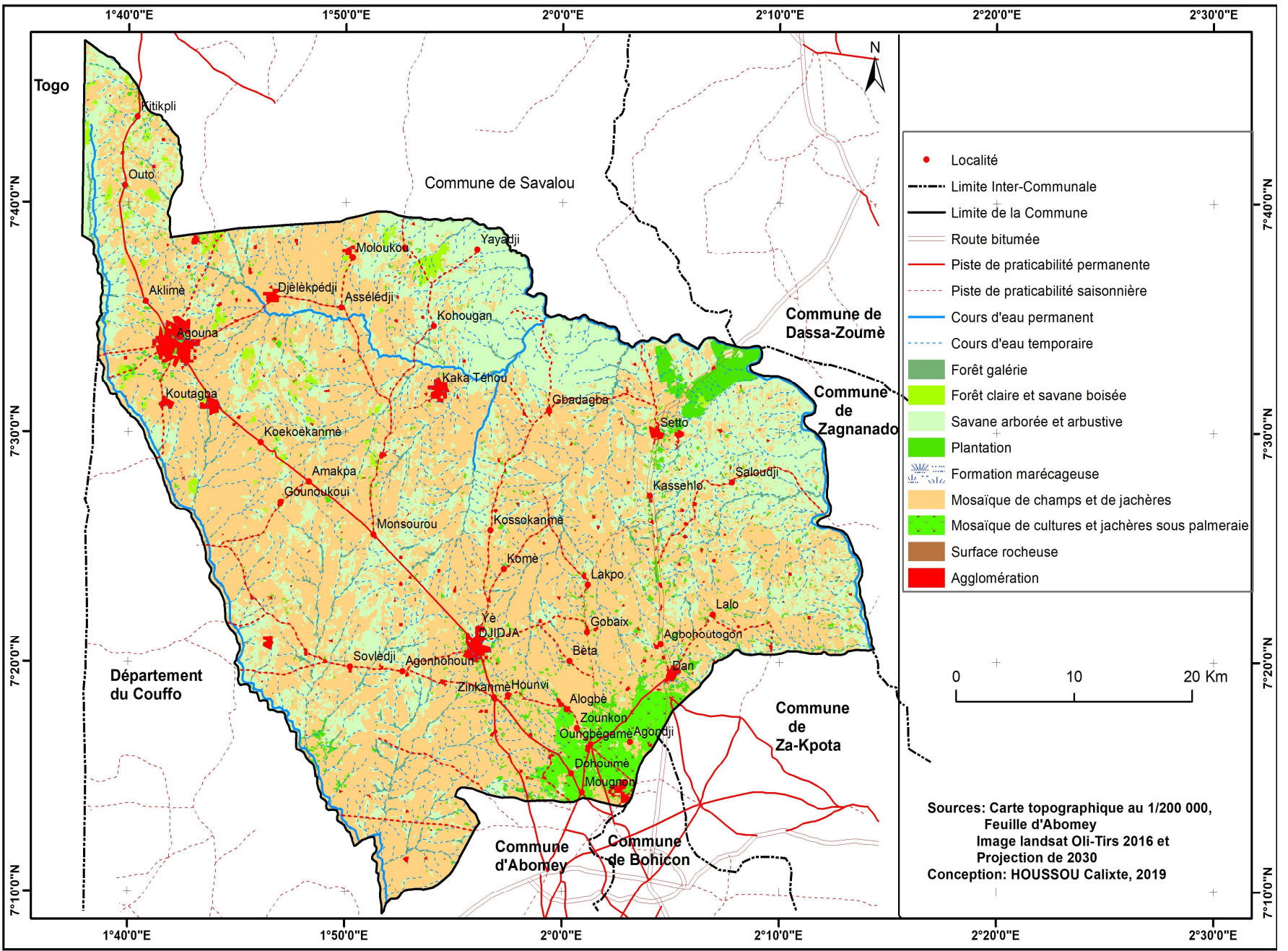

Figure 1: Socio-economic Scenario or Disaster Trend ("Red" Scenario) in Djidja Commune

Source: Extract from the results of the Spacelle model used, 2018

The analysis of this map shows that the basic considerations of this socio-economic scenario contribute to the reduction of the lifespan of plant formations, as these will be subject to anthropogenic pressures. 
In fact, it has been noted in the case of this scenario, an amplification of human pressures in particular, the extension of plantings, the intensification of shifting cultivation on slash-and-burn, the massive destruction of natural plant formations with the consequent and soil pollution, amplification of water and wind erosion followed by huge losses of agricultural land.

In addition, this scenario will accentuate the amplification of global warming due to the high production of greenhouse gases, the existence of pockets of drought due to the scarcity of rainfall. All this will intensify poverty, famine among populations and the multiplication of waterborne diseases. It is therefore important that people become aware of their part in the degradation of their living environment, which is the cornerstone of their survival on the planet earth.

In terms of environmental management, institutional measures are not implemented and endogenous environmental management strategies are ineffective. Also, grassroots people have not been aware of their behavior, which is a real threat to the environment. And these threats will intensify over time. The realization of this scenario is prejudicial to humanity and will dangerously jeopardize the existence of future generations, through the scarcity or total disappearance of certain natural resources.

\subsubsection{Environmental Stability Scenario, also called "green" scenario or "Alafia" scenario}

The assumptions of this scenario do not take into account any constraints of management of the vegetation cover, the agricultural lands, the forests and the wetlands, established in the documents of Foresight Study of the Forestry Sector in Africa (FOSA Benin, 2001). This scenario is based on the considerations contained in the National Long-term Prospective Studies, Benin 2025 "Alafia" given in the current context and which stipulates that:

- Agricultural practices have improved and are being adopted by farmers by 2030;

- The rate of forest loss is reduced from 100,000 ha / year to 50,000 ha / year by 2020 ;

- The share of wood in meeting people's domestic energy needs is reduced by $50 \%$ in favor of other energy sources such as domestic gas. 
Vol. 4, No. 06; 2019

ISSN: $2456-8643$

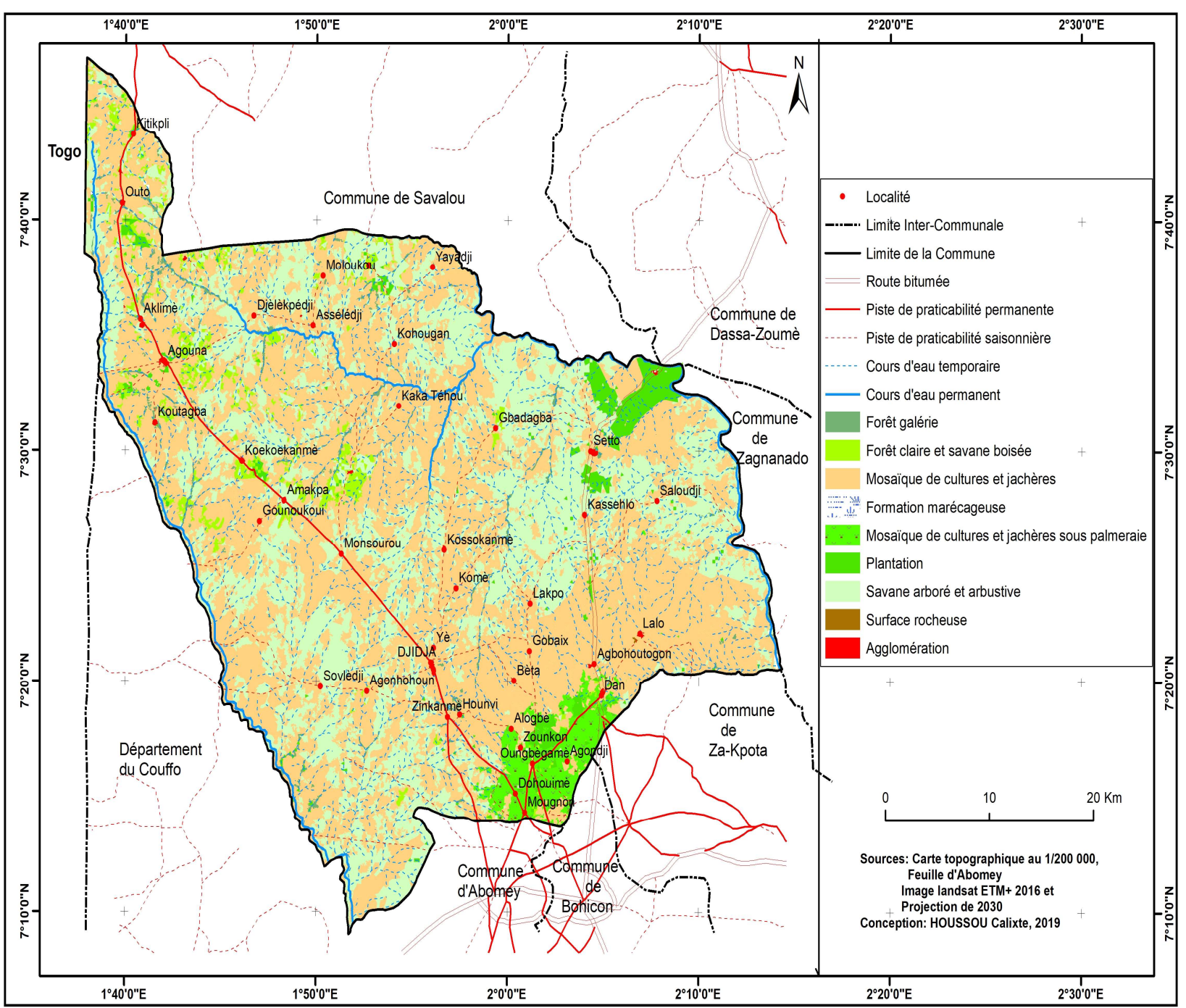

Figure 2: Scenario environmental stability or scenario "Alafia" in the municipality of Djidja

Source: Extract from the results of the Spacelle model used, 2018

According to this scenario, a stability of the different units of occupation of the lands is observed in the commune of Djidja. Based on the assumption that there is an awareness among populations that will improve agricultural practices, avoid excessive cutting of plant species, and review methods of waste management. As a result, the natural formations will recover and will be, very little or not disturbed by human pressure. In addition, soils will be little eroded, little degraded and little polluted, as well as water, and we can aspire to sustainable development in the study area. With this scenario, an early warning system will be set up for the protection and safeguarding of the environment in the municipality of Djidja, with the reinforcement of the reforestation policy. 
Vol. 4, No. 06; 2019

ISSN: $2456-8643$

This system will be coordinated by a transdisciplinary and inter-ministerial university system (Ministry of Agriculture and Environment) in synergy with the other structures working in the context of environmental protection with the involvement of local populations. the base. Among the structures, one can retain the universities, the agencies and directorates in charge of the management of the environment and the natural resources, the deconcentrated structures of the Ministry in charge of Agriculture, Livestock and Fishing, research institutions etc.

In addition, local development actors, through their various associations, are informed and integrated into the environmental management plan, through the creation and operation of several local action committees.

When these different conditions are met, we will see the 2030 horizon, environmental stability with a fair distribution of the different units of land occupation in the municipality of Djidja. This situation will prevent the municipality from the climatic disturbances of which it is victim since decades.

In short, the scenario of environmental stability or "green" scenario is that desired for a sustainable management of the environment in the municipality.

\subsubsection{Simulation of the two scenarios by 2030 in the municipality of Djidja}

The transition rules of the layers of information describing the future land occupation in the commune of Djidja in 2016 and 2030 result. The quality of the information treated with the base model in 2016 is evaluated on a test area with the matrix of confusion presented in the table.

Table I: 2016 Simulation Confusion Matrix (Basic Model)

\begin{tabular}{|lcccccccc|}
\hline & Chj & $\mathrm{Ag}$ & $\mathrm{Saa}$ & $\mathrm{FcSb}$ & $\mathrm{Fg}$ & $\mathrm{Total}$ & $\begin{array}{c}\text { Précision } \\
\text { réalisateur (\%) }\end{array}$ & pour \\
\hline $\mathrm{Chj}$ & 287 & 20 & 7 & 0 & 0 & 314 & $\mathbf{8 7 , 8}$ \\
$\mathrm{Ag}$ & 11 & 58 & 14 & 0 & 0 & 83 & $\mathbf{8 9 , 2}$ \\
$\mathrm{Saa}$ & 14 & 28 & 181 & 3 & 0 & 226 & $\mathbf{8 6 , 2}$ \\
$\mathrm{FcSb}$ & 1 & 8 & 7 & 87 & 2 & 105 & $\mathbf{8 3 , 5}$ \\
$\mathrm{Fg}$ & 0 & 0 & 1 & 2 & 78 & 81 & $\mathbf{8 3 , 8}$ \\
\hline \multicolumn{1}{c}{ Total } & 313 & 114 & 210 & 92 & 80 & 809 & $\mathbf{8 7 , 7}$ \\
\hline $\begin{array}{c}\text { Précision pour } \\
\text { l'utilisateur (\%) }\end{array}$ & $\mathbf{9 1 . 9}$ & $\mathbf{9 3 . 4}$ & $\mathbf{8 7}$ & $\mathbf{7 8 . 5}$ & $\mathbf{8 2 . 2}$ & $\mathbf{8 6 . 3}$ & $\mathbf{8 7 . 1 5}$ \\
\hline
\end{tabular}

Total accuracy: 87.15

Kappa Rating: 0.83

Sources: Results from the Spacelle model, 2018 
The overall performance of the simulation is $87.15 \%$ with a Kappa index of $83 \%$. The results according to the types of units of occupation are relatively homogeneous, since they exceed $70 \%$ of precision for the producer, with however better results for artificialized units, agglomerations, fields and fallows. The results obtained for natural formations are lower, especially that of $\mathrm{FcSb}$ with only $78.5 \%$ of well-ranked polygon. The simulation carried out using the Spacel model at the scale of the test area shows that the elaborate transition rules make it possible to maintain the spatial distribution of the various land-use units in a coherent manner, by identifying $79 \%$ of the pixels of which more than $65 \%$ are well classified. In view of all this, it was important to opt for the scenario of environmental stability that calls for an awareness of the population especially farmers, coalmen, loggers, waste management stakeholders. Indeed, this scenario can enable current generations to meet their needs but without compromising the existence of future generations.

\subsubsection{Environmental trajectory in the municipality of Djidja by 2030}

For the prospective analysis, the evolution of the units of occupation of land over time is projected by 2030 on the basis of the observed current changes and the assumptions made with respect to the socio-economic scenario "tendency toward disaster" and the green trend environmental stability scenario.

The different states of land occupation according to these different scenarios are represented in figure

7.3

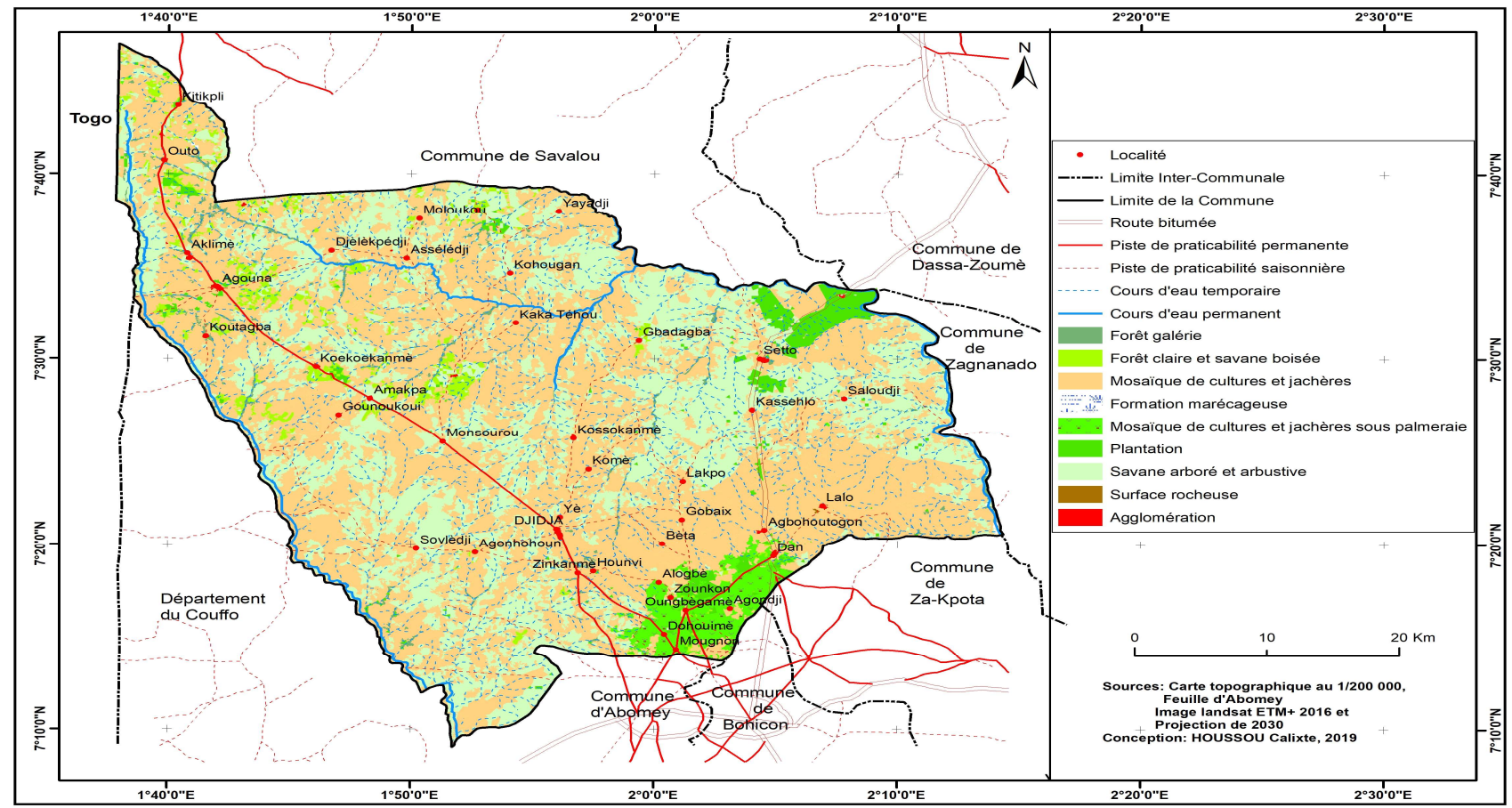


Figure 3: Land Cover Dynamics for the "Environmental Stability" Scenario by 2030

Source: Extract from the results of the Spacelle model used, 2018

Table 2 presents a summary of the projections of land-use units by 2030 according to the scenario of trend towards disaster on the one hand and toward environmental stability on the other hand in the municipality of Djidja.

Table 2: Projection of Land Cover Units by 2030 according to Disaster Trend Scenarios and Environmental Stability Scenarios

\begin{tabular}{|l|c|c|c|c|c|}
\hline Unités d'occupation & $\begin{array}{c}\text { Superficie } \\
\mathbf{1 9 9 5}(\mathbf{h a})\end{array}$ & $\begin{array}{c}\text { Superficie } \\
\mathbf{2 0 1 2}(\mathbf{h a})\end{array}$ & Tendance & $\begin{array}{c}\text { Superficie } \\
\mathbf{2 0 3 0}(\mathbf{S 1})\end{array}$ & $\begin{array}{c}\text { Superficie } \\
\mathbf{2 0 3 0}(\mathbf{S 2})\end{array}$ \\
\hline Agglomération & 824,59 & 3821,06 & 0,3 & 4197,53 & 457,76 \\
\hline $\begin{array}{l}\text { Forêt claire et savane } \\
\text { boisée }\end{array}$ & 230,76 & 0,18 & $-7,41$ & 2511,63 & 11135,88 \\
\hline Forêt galerie & 15592,46 & 1089,79 & $-9,79$ & 5286,43 & 6342,04 \\
\hline $\begin{array}{l}\text { Formation } \\
\text { marécageuse }\end{array}$ & 1719,21 & 4223,57 & $-2,29$ & 73,17 & 82,93 \\
\hline $\begin{array}{l}\text { Mosaïque de cultures } \\
\text { et jachères }\end{array}$ & 5921,24 & 3725,10 & 0,05 & 5097,08 & 6198,88 \\
\hline $\begin{array}{l}\text { Mosaïque de cultures } \\
\text { et jachères sous } \\
\text { palmeraie }\end{array}$ & 43805,09 & 58329,45 & $-5,37$ & 142011,88 & 115102,22 \\
\hline Plantation & 4906,36 & 7245,93 & 0,29 & 7120,98 & 5945,43 \\
\hline $\begin{array}{l}\text { Savane arborée et } \\
\text { arbustive }\end{array}$ & 171706,20 & 137966,44 & $-8,28$ & 62622,824 & 83651,784 \\
\hline Surface rocheuse & 635,08 & 2836,23 & $-1,01$ & 11,34 & 4,6 \\
\hline Superficie totale & 245341,00 & 219237,74 & & 228932,86 & 228921,52 \\
\hline
\end{tabular}

Source: Landsat Image 7- ETM 2010, Simulation Software: Spacella 5.1.8, GPS Data, 2018

S1: socio-economic scenario or tendency towards disaster; S2: environmental stability scenario

The analysis of this projection reveals that, by the year 2030, while the anthropic units will extend, the natural formations, that is to say the semi-deciduous dense forests, the swamps, the forests and the forests. wooded savannahs, as well as wooded and shrubby savannas will experience a sharp decline. The increase of tree and shrub savannas could be weakened later by an extension of plantations and mosaics of crops and fallows. The 2030 changes that will be observed in terms of land occupation, will be at the expense of plant formations and in favor of savannas with agricultural influence or even agglomerations. Indeed, with an annual regression rate of $9.79 \%$, forest areas will disappear at an alarming rate. They will be followed by wooded and shrubby savannas for a regression rate of $8.28 \%$ and clear forests and wooded savannas (regression rate of $7.41 \%$ ). The evolution of farmland is a result of population growth as well as 
the prominence given to agriculture by the people of Djidja commune, but also to charcoal and firewood production activities.

With this trend, agricultural land will become more scarce, with the risk of disappearing natural formations in general and forests in particular. This translates into an increase in the size of the study area, which is rather unstretchable. It is obvious that the projection of the surfaces of the units in 2030 takes into account other explanatory parameters of the dynamics of the occupation of the grounds and or a reallocation of the different units constituting formations.

The impact of the results of the scenarios developed is that, from now on, a dynamic and voluntary policy of rational management of the environment should be put in place. Decisionmakers and local elected representatives must engage in a vast campaign of reforestation or reforestation, which will not only be limited to forests, but will also extend to the rational management of the living environment of the population of the municipality for the success of the local development.

\subsubsection{Institutional measures of environmental management in the municipality of Djidja}

In view of this environmental trajectory in the municipality of Djidja by 2030, the institutional measures to be taken concern the implementation of all the laws and texts that regulate the protection and protection of the environment, in the Republic of Benin in general and in the commune of Djidja in particular.

Indeed, in order to cope with environmental problems, Benin, in addition to the efforts that are being made, collaborates closely with the main international organizations involved in the field of the environment since the Stockholm Conference in 1972, namely: United Nations, Francophonie organizations, the European Union (EU), the Organization of African Unity $(\mathrm{OAU})$, certain regional and sub-regional bodies (Council of the Entente, ECOWAS, UEMOA), the partner countries under the bilateral conventions (Togo / Benin, Benin / Nigeria, Benin / Niger, Benin / Burkina-Faso), the technical and financial partners such as the World Bank, UNDP, UNEP, the various cooperations (French, German, Belgian, Swiss, Dutch), etc. All these institutions and organizations collaborate with the Ministry of Environment and Sustainable Development to meet the needs of people in terms of rational management of the environment and the living environment. This ministry, through its various directorates and structures under guardianship, performs the main tasks assigned to it by the texts in force.

To achieve its objectives, several Directorates, Agencies, Institutes, Societies, Programs, Projects are instituted by various official acts. One of its official acts is the Framework Law on the Environment.

Law No. 98-030 of 12 February 1999 on a framework law on the environment in the Republic of Benin lays down the bases of environmental policy and organizes its implementation in application of the provisions of Articles 27, 28, 29, 74 and 98 of the Constitution of the Republic of Benin. This law prescribes in its article 3, six (6) general principles which govern the management of the environment in Benin; these principles are: 
Vol. 4, No. 06; 2019

ISSN: $2456-8643$

- The principle of belonging to the Beninese environment considered as national heritage, to the common heritage of humanity;

- The principle that gives Beninese citizens the right to a healthy, satisfying and hard environment

- The principle of public participation in the formulation and implementation of environmental policies, including the strengthening of the power of recognized associations (Article 109 paragraph 2);

- The principle of strengthening national capacities for environmental policy management;

- the principle of responsibility and redress for environmental damage which is nothing more than the "polluter pays" principle.

Apart from the sectoral special laws and laws that governed the environment, the Framework Law on the Environment in the Republic of Benin remains the current and the only legal reference text on the environment in Benin. This law provides for environmental crimes punishable by criminal imprisonment for 5 to 20 years and a fine of 25,000,000 CFA francs to $500,000,000$ CFA francs. These crimes concern the transit, the storage, the landfill, the dumping on the national territory of toxic or polluting waste or signature of an agreement to authorize such activities (Article 118) and various crimes of attack on the environment. The penalties are high fines and / or imprisonment plus seizure or withdrawal of authorization, precautionary measures, injunctions, reinstatement, if any. (Articles 114, 115, 116, 117, 121, 122). Finally, various fines that could be committed to the environment and incurred fines ranging from 50,000 CFA francs to 500,000 CFA francs.

In addition, the legal system for environmental protection includes a set of cross-cutting procedures made compulsory by law and decrees. It is :

The Environmental Impact Assessment provided for in Articles 87 to 93 of the Framework Law and Articles 1 to 28 of the Decree on Environmental Impact Assessment in Benin and in the General and Sector Impact Assessment Guides on the environment ;

- The Environmental Audit (Articles 94 to 95 of the Framework Law and Articles 1 to 53 of the Decree on Environmental Audit in Benin);

- The Public Audience on the Environment (Articles 96 to 102) of the Framework Law and Articles 1 to 22 of the Public Hearing Decree in Benin);

- Emergency plans or environmental planning (sections 103 to 104 of the Framework Act).

\subsubsection{Provisions for local environmental governance}

With the implementation of decentralization and the promotion of local development on the one hand and at the end of the study on Environmental Governance and in the light of the institutional and organizational audit of the Ministry in charge of the Environment, on the other hand, consultation was necessary for a clear and transparent distribution of the roles, roles and 
responsibilities of the different actors responsible for environmental issues at all levels, for determining the conditions under which the parties should intervene and for identification of the means necessary for the implementation of their missions. This consultation led to the organization on 22 and 23 January 2004 in Cotonou, the national forum on the roles and responsibilities of the State, Municipalities and Civil Society in Environmental Governance. This National Forum on Governance

Environmental initiated by the State through the Ministry of Environment, Housing and Urban Planning (MEHU), has gathered nearly two hundred delegates from seventy seven (77) municipalities of Benin, the organizations of Civil Society and all Ministries.

It was during this grand Forum, to identify and define the roles and responsibilities of each party for a good environmental management in the perspective of a shared management of the environment and the reduction of poverty. The Forum aims to:

$\square$ Clarify, from the diagnosis, the missions, roles and responsibilities of each party;

Formulate proposals for strategies that make the different actors more accountable in their roles;

Translate, through a charter, the commitments of the different parties, on a consensual basis and from a more appropriate framework, for good governance between the State, Civil Society and the Decentralized Communities;

To obtain effective membership and a minimum of commitment on the part of the actors for a good management of the environment.

This forum recommended the establishment of a charter on environmental governance. The National Charter on Environmental Governance is intended to promote the search for processes and solutions for shared management of the environment. It aims to optimize the management of the environment. It contributes to the fight against poverty and sustainable development. It reflects the desire for transparency, ethics, ethics and the search for efficiency and performance in environmental policy (MEHU 2004). Benin's national charter on environmental governance aims to:

Reaffirm the established principles of environmental governance;

Recognize the changing environmental roles at the State, municipal and civil society levels, especially since the implementation of the territorial administration reform;

Define the roles and responsibilities of the actors with a view to involving them more and leading them to a genuine commitment to environmental governance;

Create or strengthen mechanisms promoting environmental governance;

Provide the means necessary for its implementation;

Mobilize and distribute resources equitably among the different actors. 
The National Charter on Environmental Governance is based on eleven (11) principles namely: the rule of law, the integration of the environment into policies, environmental protection, accountability and the polluter pays, sustainable development, prevention and precaution, participation, knowledge and information.

For good environmental management at local level, it is necessary to clarify the responsibilities and roles of the various actors involved in this management, to know the

State responsibilities at the deconcentrated level (local policies and guidelines, legislation, definition of quality standards, control) in the management of the environment. It will be necessary to understand the powers that have been transferred to the commons in the field of the environment and which have been defined in articles 93 to 96 of the law n ${ }^{\circ}$ 97-029 of January 15, 1999 relating to the Organization of the Communes in the Republic of Benin. This will enable the municipality to adopt a strategic and participative approach in environmental management in order to avoid a piecemeal approach. The municipality will be able to rely on the local planning documents that are: the Communal Development Plan, the Master Development Plan of the Commune, the Local Agenda 21, the Municipal Programs of Environmental Actions and other environmental projects. It is also important to underline the importance of the intervention of the Commune in a number of tasks that affect the daily life of citizens and the improvement of their living environment and which are, therefore, very crucial for the environmental governance. These include the housing estate, drinking water, household waste, building permit, public and family latrines, solid and liquid waste management, public squares and gardens, food hygiene., public transport, cemeteries, etc.

In addition, good local environmental governance requires the municipality to have partnerships that make it possible to involve all the actors whose assistance, whatever its form, is useful for the good execution of the communal tasks. From this point of view, the municipality will have to develop the partnership with the State, the other communes (intercommunality), the Civil Society as well as the decentralized cooperation.

This environmental governance, calls for an analysis of the financing methods of environmental actions that relies as much on local internal resources as on resources mobilized at the level of the State, the Solidarity Fund Intercommunale (FSIC), the Institution of Local Government Financing (IFCL) and decentralized cooperation.

Finally, local environmental governance is very important for the promotion of sustainable human development in each municipality, which requires municipal teams to take a strategic approach and a unifying role in environmental management.

\subsubsection{Endogenous and Corrective Environmental Management Measures}

Forest protection is now an imperative because their gradual disappearance is slowly, but surely, reducing the country's economic potential. To this end, Benin has put a lot of effort into protecting its ecological heritage through the development of Forest Management Plans (PAF), Supply Master Plans (SDA) in wood energy. Participatory forest management plans for communal and communal forests in Djidja commune must be developed and implemented in an 
appropriate manner with the different stakeholders in forest management for good management of the reserve ecosystem. The participatory forest management plan is a planning tool that protects forest ecosystems and replenishes the vegetation cover where it is degraded and this by noble species so that the vegetation cover can play its full role.

The wood energy supply master plans must be developed for the Djidja commune and implemented by the various stakeholders dealing with forest resources management issues in the commune. The master plan wood energy supply is a planning tool that manages the use of firewood and charcoal as domestic energy by the people on the one hand and to control the serious consequences of the scarcity of wood energy in terms of energy supply on the other hand.

In addition, the commune of Djidja did not remain on the sidelines of environmental initiatives. It tries to implement in its Development Plan of the Commune, reforestation activities. Indeed, given the impact of deforestation on the environment and on the well-being of the populations, the communal authorities as well as the grassroots populations put in place a reforestation policy which involves trees. In the whole commune, reforestation activities constitute, for $75 \%$ of those surveyed, a powerful means of conserving forest resources and protecting the soil against all forms of erosion. Tree shading traps sunlight and protects the soil by keeping it constantly moist (Vigan, 2003).

In the commune on the site of Colobi, a beginning of reforestation began on nearly 400 hectares and will be able to be amplified with the other localities of the municipality or the other communes of Benin. Reforestation promotes the restoration of wood resources used in the development of charcoal and firewood manufacturing activities.

In view of the sustainability of these initiatives, it is important to implement the following complementary measures:

Reduce the anarchic slaughter of woody species. Here, the use of domestic gases instead of charcoal and firewood should be encouraged. Also, it is necessary to reforest the protected areas, to respect the laws which govern the protection and the safeguarding of the natural resources in general and the forests in Republic of Benin in particular;

$\square$ Encourage the use of stoves in homes, which will limit the pressures on plant formations;

Get people to subscribe to pre-collection structures so that waste is better managed, through efficient treatment and recovery systems.

In order to reinforce the existing endogenous and institutional measures, it is important to analyze the contents of the environmental management scenario in the study area. In addition, other tools and instruments to control the management of the environment have been instituted both at the municipal level. These are the Municipal Environmental Action Plans (EMAPs) resulting from the National Environmental Policy (NEP).

Finally, in the face of multiple threats to the environmental components in Djidja commune, endogenous measures are taken by grassroots populations to reconcile human activities and the environment in connection with local development. These measures include improving cultural 
practices, behavior change communications $(\mathrm{CBC})$ and sensitization by wise men and other moral and religious authorities. Improving cultural practices consists of:

Encourage the mulching system, which consists in abandoning grass weeds without burning them; which combats wind erosion and allows the restoration of soils by the decomposition of the leaves. In addition, this practice makes it possible to maintain moisture in the soil, which is conducive to the development of agriculture;

$\square$ Reduce the use of chemical fertilizers and pesticides by the Targeted Staging Method (LEC), which consists of intervening only on the crop at the precise times when it is invaded by the parasites with reduced doses of insecticide and in a time-limited manner;

Diversify agricultural production through polyculture especially food crops as desired by farmers in order to make their production profitable and increase their income without using chemical fertilizers;

Develop lowland areas to be able to grow off-season crops. This measure will limit the pressures on agricultural lands and lead to their rapid impoverishment which induces the use of chemical fertilizers;

Introduce integrated agriculture using fewer inputs. To this end, organic farming must be generalized by encouraging the use of poultry droppings and organic manure. This measure will make it possible not only to fight against the chemical pollution of the soil but also that of the water;

Ensure the sustainability of food crops and cash crops ecologically, economically and socially. It would then be necessary to develop sustainable and concrete farming systems with the groups of selected producers;

\section{CONCLUSION}

Given the inefficiency of the strategies already developed by the populations of Djidja commune, environmental management scenarios are developed to make options for environmental sustainability in the municipality of Djidja. As part of this study, three scenarios are envisaged. This is the environmental stability scenario (green), the disaster scenario (red) and the neutral scenario. For the environmental stability scenario, it is envisaged that the populations become aware of the risks they run by degrading the natural resources on which they depend for their monitoring.

In the context of the disaster scenario, there is no awareness of the populations, therefore, an amplification of the factors of degradation. And if nothing is done, the trend will accumulate and the environmental destruction and disaster. The changes of behavior so desired will not be there to limit or mitigate the effects of rampant demography and its corollaries on the natural resources of the municipality of Djidja. There will be an uncontrolled onslaught of people on resources.

In response to the threats to the environment, institutional and corrective measures are taken to reverse the trend. The analysis of these measures reveals that institutional measures are limited to 
Vol. 4, No. 06; 2019

ISSN: 2456-8643

the drafting of laws and laws aimed at safeguarding the environment. Unfortunately, these texts and laws are not always applied because of the bad will of actors at all levels and populations.

As for the endogenous measures of environmental management, the populations develop strategies such as the improvement of cultivable practices, reforestation, etc.

\section{REFERENCES}

ADAM S.K., BOKO M., (1993). The Benin. New edition. Cotonou, Benin, Editions of Flamboyant-Edicef, $93 \mathrm{p}$.

ADJINDA, A.S. AND HOUNTON, K.N. (1997): Contribution to the study of the dynamics of the environment in a reception area: the case of the sub-prefectures of Savè, Ouèssè and Tchaourou. Master's thesis, Polytechnic College

AFOUDA F., HOUSSOU C. S., TENT B., VISSIN E., OGOUWALE E., TOTIN H. and YABI I. (2003): Coal economics and sustainability in the municipality of Djidja. Consultation Report, PADECOM-Zou, Abomey, $59 \mathrm{p}+$ Appendices.

AGBAHOUNGBA C., (2005): management of natural forest resources and biodiversity in the municipality of DJIDJA. Master's thesis in Geography, FLASH / UAC, 103p.

AGBOMAHENAN S., (2007): Socio-economic and environmental impacts of pottery activities in the municipality of Djidja, Master's thesis in geography, University of Abomey Calavi, Benin. $77 \mathrm{P}$.

AKOEGNINOU A., AND AKPAGANA K., (1997): Cartographic and vegetation dynamics study of the classified area of the Savalou hill (Benin). Botanical Journal of the Société botanique de France, No. 3, p. 69-81.

AROUNA O., (2012): Mapping and Predictive Modeling of Spatio-temporal Changes in Vegetation in Djidja Commune in Benin: Implications for Spatial Planning, Ph.D. Thesis, Faculty of Letters, Arts and Humanities and Faculty of Science and Technology, University of Abomey-Calavi, Abomey-Calavi, Benin, 246 p.

AROUNA O., TOKO I., DJOGBENOU C.P., \& SINSIN B., (2010): Impact of Spatiotemporal Dynamics of Land Use on Vegetation in Sudano-Guinean Zone in Benin. Rev. Sc. Env. United. Lome (Togo), 6: 161-186.

AROUNA O., TOKO IMOROU I., GIBIGAYE M., ALLE P. and TENT B., (2017): "Comparative analysis of the state of conservation of classified forests, community forests and sacred forests in southern Benin ( West Africa) "in International Journal of Innovation and Applied Studies, Vol. 19, No. 1, pp. 123-139.

ASECNA, (2011): Climatic data from Bohicon meteorological station, Benin. 
Vol. 4, No. 06; 2019

ISSN: 2456-8643

HOUNTONDJI Y. C. H., (2008): Environmental dynamics in the Sahelian and Sudanian zones of West Africa: Analysis of changes and assessment of vegetation cover degradation. University of Liège, Belgium, 153.

INSAE, (2013): General Census of Population and Housing. Cahier of the villages and district of city. Department of Zou. Directorate of Demographic Studies, Cotonou, Benin, 24p.

INSAE, (2013): General Census of Population and Housing4 Atlas monograph. Cotonou, Benin, $272 \mathrm{p}$

MAMA J. V., \& HOUNDAGBA J. C., (1991): Preparatory document for the United Nations Conference on Environment and Development. Report of Benin. Cotonou, Benin, 116 p.

OLOUKOI J., MAMA V., AGBO F., (2006): Modeling land-use dynamics in the Hills Department of Benin. INRAB-Benin / RECTAS-Nigeria, p. 8.

OREKAN VA, (2007): Implementation of the local model CLUE-s to spatial transformations in the Benin Center to the means of socio-economic data and remote sensing ", PhD Thesis of Geography, University of Bonn, Bonn, Switzerland, (2007) 204 p.

PDC, (2010): Development Plan of the Municipality of Djidja. 96 p.

ENVIRONMENTAL ACTION PLAN, (1993): Environmental Action Plan (1993), Ownership Unit Environ \& Soc Sustainable Dev VP (ESD). Climate Policy \& Finance (CPF).

SINSIN B., SINANDOUWIROU T.H., \& ASSOGBADJO A., (2000): Ecological characterization of two fodder species of Benin: Khaya senegalensis (desv) and Afzelia africana sm. IPGRI / SAFORGEN study report, Cotonou, Benin.

SINTON L. O., AGBOSSOU E. K, \& DEGNISSODE B., (2013): Dynamics of degradation of gallery forests and filling of the Agbado watercourse in the department of the hills in Benin. International Journal of Biological and Chemical Sciences, 7 (4), 1555-1567.

TOHOZIN A. Y., (1999): Agricultural Policies, Farming Strategies and Rural Dynamics in the Lower Valleys of Oueme in Benin and the Volta in Ghana. PhD Thesis, University Paul Valery, $511 \mathrm{p}$. 